\title{
HIV-1-associated neurocognitive disorder: epidemiology, pathogenesis, diagnosis, and treatment
}

\author{
Christian Eggers ${ }^{1}\left(\mathbb{D} \cdot\right.$ Gabriele Arendt $^{2} \cdot$ Katrin Hahn $^{3} \cdot$ Ingo W. Husstedt $^{4}$. \\ Matthias Maschke $^{5}$ Eva Neuen-Jacob ${ }^{6} \cdot$ Mark Obermann $^{7}$. Thorsten Rosenkranz ${ }^{8}$. \\ Eva Schielke ${ }^{9} \cdot$ Elmar Straube $^{10} \cdot$ For the German Association of Neuro-AIDS und \\ Neuro-Infectiology (DGNANI)
}

Received: 22 February 2017/Revised: 30 April 2017 / Accepted: 2 May 2017/Published online: 31 May 2017

(C) The Author(s) 2017. This article is an open access publication

\begin{abstract}
The modern antiretroviral treatment of human immunodeficiency virus (HIV-1) infection has considerably lowered the incidence of opportunistic infections. With the exception of the most severe dementia manifestations, the incidence and prevalence of HIV-associated neurocognitive disorders (HAND) have not decreased, and HAND continues to be relevant in daily clinical practice. Now, HAND occurs in earlier stages of HIV infection, and the clinical course differs from that before the widespread use of combination antiretroviral treatment (cART). The predominant clinical feature is a subcortical dementia with deficits in the domains concentration, attention, and memory. Motor signs such as gait disturbance and impaired
\end{abstract}

Christian Eggers

Christian.Eggers@BBLinz.at

1 Department of Neurology, Krankenhaus Barmherzige Brüder, Seilerstätte 2, 4021 Linz, Austria

2 Neurologische Klinik, Universitätsklinikum Düsseldorf, Düsseldorf, Germany

3 Neurologische Klinik, Charité, Berlin, Germany

4 Klinik für Neurologie, Universitätsklinikum Münster, Münster, Germany

5 Neurologische Abteilung, Brüderkrankenhaus Trier, Trier, Germany

6 Institut für Neuropathologie, Universitätsklinikum Düsseldorf, Düsseldorf, Germany

7 Direktor des Zentrums für Neurologie, Asklepios Kliniken Schildautal, Seesen, Germany

8 Neurologische Abteilung, Asklepios-Klinik Hamburg-St. Georg, Hamburg, Germany

9 Praxis für Neurologie Berlin-Mitte, 10117 Berlin, Germany

10 HIV-Schwerpunktpraxis, 30890 Barsinghausen, Germany manual dexterity have become less prominent. Prior to the advent of cART, the cerebral dysfunction could at least partially be explained by the viral load and by virus-associated histopathological findings. In subjects where cART has led to undetectable or at least very low viral load, the pathogenic virus-brain interaction is less direct, and an array of poorly understood immunological and probably toxic phenomena are discussed. This paper gives an overview of the current concepts in the field of HAND and provides suggestions for the diagnostic and therapeutic management.

Keywords HIV-1 infection - AIDS - Neurocognitive disorder - Dementia $\cdot$ HIV-associated neurocognitive disorders (HAND)

\section{Introduction and terminology}

Since the introduction of combined antiretroviral therapy (cART) in 1996, the HIV-1 infection has become a treatable condition. However, HIV infection is an incurable disease as attempts to eradicate the virus have so far been unsuccessful. The cerebral manifestations of HIV infection with the disturbance of cognitive, behavioural, motor, and autonomous functions $[2,72,83,113]$ remain an issue in the everyday practice of HIV medicine. The older terms HIV encephalopathy and AIDS dementia complex have been replaced by the term HIV-associated neurocognitive disorder (HAND). The current terminology of HAND [1] is based on a 2007 revision of the older classification of 1991 and was triggered by the fact that the disease course was considerably altered by cART (Table 1 ). The current terminology of neurocognitive impairment (NCI) comprises the category of asymptomatic neurocognitive impairment 
Table 1 International terminology of HIV-associated neurocognitive disorders (HAND) [1]

\begin{tabular}{ll}
\hline $\begin{array}{l}\text { HIV-1-associated asymptomatic } \\
\text { neurocognitive impairment (ANI) }\end{array}$ & $\begin{array}{c}\text { Acquired impairment in cognitive functioning (NCI), involving at least two ability domains, } \\
\text { documented by performance of at least } 1,0 \mathrm{SD} \text { below the mean }{ }^{\mathrm{a}} \text { on standardized } \\
\text { neuropsychological tests }\end{array}$ \\
& $\begin{array}{c}\text { The cognitive impairment does not interfere with everyday functioning (e.g., mental acuity, } \\
\text { inefficiency in work, homemaking, or social functioning) }\end{array}$ \\
HIV-1-associated mild neurocognitive & Neuropsychological test results as with ANI \\
disorder (MND) & At least mild interference in daily functioning (self-report or witnessed by knowledgeable others) \\
HIV-1-associated dementia (HAD) & Neuropsychological test results as with ANI, but performance in cognitive testing impaired by at \\
& least 2 SD of the mean \\
Marked interference with day-to-day functioning
\end{tabular}

\footnotetext{
${ }^{a}$ Adjusted for age-education-appropriate norms

b The neuropsychological assessment must survey at least the following abilities: verbal/language; attention/working memory; abstraction/ executive; memory (learning; recall); speed of information processing; sensory-perceptual, motor skills
}

(ANI), mild neurocognitive disorder (MND), and HIV-associated dementia (HAD). Motor and psychiatric findings are no longer required for diagnosis. We do, however, still recommend to ascertain motor and affective symptoms and signs, as they are a constitutive elements of HAND and are relatively easily quantifiable irrespective of the patients ethnic and educational background [3, 98]. In a clinicalpathologic study, a good agreement of the histopathological diagnosis of HAND with the new classification scheme was found [12].

\section{Epidemiology}

Since the introduction of cART in 1996, the incidence of HIV-associated diseases in the industrialised countries has decreased to the extent that the life expectancy of HIVinfected people is now close to that of non-infected individuals [68]. The incidence of HAND was found to be less decreasing than that of the other AIDS-defining conditions [25], although the most severe forms of dementia are much rarer now The prevalence of neurocognitive dysfunction caused by HIV itself (as apposed to opportunistic infections) increases over time after infection and is currently estimated at $20-50 \%[55,100,111]$. HAND is a treatable condition, and the treatment effect is larger in cARTnaive and more impaired, i.e., demented, patients. Several authors reported patients with suppressed plasma viraemia who developed chronic progressive and at times fluctuating cognitive dysfunction $[1,5,124]$. One longitudinal study of cognitive dysfunction in asymptomatic HIV-infected individuals yielded stable cognitive performance over 5 years [18]. Patients who were diagnosed and treated early after infection had a low prevalence of NCI [19]. HIV patients, however, who started their cART late, i.e., with a low CD4 cell count, and where observed over several years were found to be cognitively somewhat more impaired than
HIV-negative individuals [75]. Longitudinal cohort observations found that many patients with asymptomatic neurocognitive impairment (ANI), even with suppressed plasma viral load, eventually developed symptomatic NCI [45]. Although the widespread use of cART has lead to a marked decrease in the number of patients with more severe manifestation of HAND [90], less severe NCI remains frequently being observed in clinical practice, and these manifestations now occur earlier during the course of HIV infection [54, 55, 99, 111].

HAND is associated with shortened survival [105]. In patients with a known time point of the primary HIV infection, an early decrease of CD4 cell count and high initial plasma viraemia were found to predict NCI [69]. Patients in whom the primary HIV infection is clinically manifest have an earlier onset and a more rapid course of NCI [127].

In 2015, 29,747 people were newly diagnosed with HIV in the European Union and European Economic Area, with a rate of 6.3 per 100,000 (http://ECDC.europa.eu; accessed March 2017).

The mean age of people living with HIV is increasing. The highest prevalence is now in the age group around 50 years. This implies that the differential diagnosis of NCI of HIV-infected patients needs to encompass virus-independent and age-associated diseases. The odds of developing HAND increase with rising age $[13,71,121]$.

\section{History and clinical findings}

HAND is characterised by an insidious onset with slow progression. If the neurocognitive disorder has an onset of less than 4 weeks competing aetiologies need to be excluded. At the time of clinical and neurocognitive testing, the patient must not be febrile, extremely tired, sedated by medication, or suffer from an acute disease with an 
impact on his physical and mental condition. In this situation, a repeat clinical and psychometric examination under suitable conditions is required.

In the earlier stages, patients with HAND complain of difficulties in concentration and memory and of impaired executive functions. When the disease progresses, signs of psychomotor slowing with depressive and other affective symptoms such as irritability as well as mild and sometimes subclinical motor signs will be apparent. The fullblown dementia that, if untreated, may progress to a bedridden state with mutism and incontinence is discussed to be a distinct phenomenon with a partially different pathogenesis.

Expressing complaints about mental dysfunction is not the same as actually having objective impairment. Patients in whom neuropsychological testing actually demonstrates NCI tend to underestimate the degree of their dysfunction, while the opposite is true for patients with depression [119]. This is why a history given by informants close to the patient often is very important.

HAND does not reduce the level of consciousness nor does it cause unequivocal focal signs or neck stiffness. Neither are psychiatric manifestations such as illusion and paranoia sufficient to make the diagnosis of HAND. The co-incidence of HAND and affective and schizophrenic psychosis is very low [53]. Some $5-10 \%$ of patients with more advanced HAND may develop focal and generalised epileptic seizures [130].

\section{Ancillary diagnostic procedures}

Neurocognitive testing, radiology studies, biochemical analyses (cerebrospinal fluid, CSF), and electrophysiological studies (EEG, somatosensory evoked potentials, SEP) may aid in the diagnosis of HAND. HAND is, however, a clinical diagnosis, and no technical finding in isolation warrants the diagnosis of HAND.

\section{Neurocognitive testing}

Quantitative neurocognitive testing is the most suitable means and the gold standard to ascertain NCI. Testing should include the neuropsychological domains speech, attention/working memory, abstraction/executive function, learning/recall, information processing speed, and motor functions [67]. Table 2 lists some frequently used tests.

Where comprehensive testing is not possible, shorter tests may be applied. The HIV dementia scale features ageand education-adjusted norms [78]. The International HIV dementia (IHDS) scale is validated and independent from education [101]. The Montreal cognitive Assessment (MoCA) test is well established in Alzheimer's disease and has been applied to diagnose HAND. Their sensitivity and specificity are, however, very limited [58, 77].

Among the electrophysiological tests, the value of the EEG is to differentiate from epilepsy-associated psychoorganic states. In HAND, the EEG is usually normal, but may show slight generalised slowing without focal findings. The finger tapping test is sensitive to motor slowing [2].

Magnetic resonance imaging (MRI) of the brain is the most sensitive imaging modality. It should encompass the following: axial DWI, T2, TIRM/FLAIR, and T1 series; additionally $\mathrm{T} 1$ with contrast enhancement (when appropriate) and the T2 or TIRM/FLAIR series in the sagittal plane. MRI often shows hyperintense signal in the deep white matter and in the basal ganglia of the cerebral hemispheres, but this finding is not specific for HAND [117]. As opposed to progressive multifocal leukoencephalopathy (PML), the cortical U-fibres are not involved in HAND. Enlargement of ventricles and the cortical sulci may occur early in the disease course [92]. Space occupying lesions and focal contrast enhancement are incompatible with the diagnosis of HAND. The main use of brain imaging is, however, the exclusion of diseases mimicking HAND.

Modern MR-based techniques such as MR spectroscopy, magnetization transfer ratio (MTR), diffusion tensor imaging (DTI), and voxel-based morphometry have all been shown to correlate structural and biochemical changes with neurocognitive parameters [17, 52, 60, 93], but they are not yet established in clinical routine.

With a large part of the HIV-infected population growing old, HIV-associated MRI changes need to be differentiated from white matter hyperintensities (WMH) associated with cerebral small vessel disease, and both may co-exist. In a study with cART-treated subjects, the extent of the white matter hyperintensities was more closely correlated with the subject's age and blood pressure than with virological parameters [76].

The value of psychiatric examination lies in the differentiation of HAND from major depressive disorder as depression frequently occurs in HIV infection, and there is an overlap between the symptoms of depression and HAND [125].

Cerebrospinal fluid (CSF) is mainly taken to diagnose CNS opportunistic infections and CNS lymphoma (Table 3). In patients with HAND, the CSF white cell count may be normal but frequently shows a mononuclear pleocytosis of up to 20 cells/ $\mu$ l. With severe immunosuppression, it may be decreased. Total protein and albumin concentrations may be slightly elevated (blood-brain barrier disruption). Oligoclonal bands and increased IgG-index indicate autochthonous immunoglobulin production within the CNS. However, these findings, including slight 
Table 2 Neuropsychological test methods suitable for the screening and diagnosis of HAND [1]

\begin{tabular}{lll}
\hline & Test & Cognitive domain/function \\
\hline $\begin{array}{c}\text { Simple tests (preferred } \\
\text { for screening) }\end{array}$ & HIV dementia scale [7, 78], International HIV dementia scale [101]; & Working/short-term memory, attention, \\
In-depth testing ("gold & MoCA test [58, 86]; "NEU screen" [81] & Trail-making, grooved peg board, digit-symbol test, reaction time \\
standard") & Prail-making, Stroop colour-word-interference test, digit-symbol test & Abstraction \\
& Copy drawing of Reye figure, mosaic test & Visuoconstruction \\
& $\begin{array}{l}\text { Repeating of multi-digit-numbers, Rey-Auditory-Verbal Learning test, } \\
\text { digit-symbol test }\end{array}$ & Attention and memory \\
\hline
\end{tabular}

For interpretation, the results are adjusted for age and length of education

pleocytosis, are non-specific and are frequently present even in the asymptomatic stages of HIV infection [35]. In patients on cART, the CSF cell count is lower than in untreated subjects, and this applies especially to cART regimens with CSF penetrating substances [70]. A CSF pleocytosis that arises within weeks after initiation of cART may suggest an immunological response to HIV in the context of immune reconstitution. In untreated patients, there is a weak but statistically significant correlation of (higher) CSF viral load with HAND [6, 73]. However, this association is no longer true for individuals on cART [21, 55, 74, 104]. In CNS opportunistic infections, there is an elevated HIV RNA concentration in the CSF, thereby restricting the use of HIV viral load in the CSF for the diagnosis of HAND [79].

CSF levels of A $\beta 42$ (a cleavage product of the amyloid precursor protein, APP) and the protein $\tau$ (tau) have been found to be decreased and increased, respectively, in HAND patients $[15,115]$. The patient populations were small, however, and these parameters are not yet recommended for clinical routine. Even in patients with suppressed plasma virus, neopterin as a marker of immune activation and neurofilament-light as a marker of tissue damage are elevated in the CSF and correlate with NCI [26].

\section{Differential diagnoses}

In view of an aging HIV-population, a declining incidence of CNS opportunistic infections, and HIV infection being a vascular risk factor, other aetiologies of neurocognitive dysfunction need to be considered. These include nonHIV-associated conditions such as Alzheimer's disease, cerebral small vessel disease with vascular dementia, dementia with Lewy bodies, communicating hydrocephalus, etc. Table 3 lists the most important differential diagnoses and the appropriate clinical work-up.

\section{Pathogenesis and neuropathological findings}

In patients with no or an unsuccessful antiviral treatment, the morphological hallmark of HAND is HIV encephalitis and HIV leukoencephalopathy. The encephalitis is characterised by disseminated infiltrates of lymphocytes, macrophages, and multinucleated giant cells [8], while leukoencephalopathy implies bilateral diffuse loss of myelin in the hemispheric white matter alongside with astrocytosis and microglial infiltration [9]. The most typical (albeit not pathognomonic) finding is the multinucleated giant cells, which arise from fusion of macrophages.

During the course of primary infection, HIV enters the brain parenchyma via infected lymphocytes and monocytes and probably by transependymal migration [48]. This is the reason why inflammatory CSF changes are already present in the asymptomatic stages of the infection in almost all individuals $[35,70]$. The basal ganglia and the frontal white matter are the most early and intensely affected brain regions [84]. The cellular basis of carriage and production of virus are the immunocompetent cells such as perivascular microglia and lymphocytes [106]. Neurons, astrocytes, and oligodendroglia are not or only minimally infected. They are, however, affected as evidenced by loss of synapses and neurons [38, 47], by apoptosis as well as by production of osteopontin, a pro-inflammatory cytokine [109]. Many authors found a positive correlation between the amount of virus and viral products (e.g., gp120 und gp41) and the extent of histopathologic changes in the brain $[24,66,87,118,128]$. In addition, the grade of clinical neurologic dysfunction is related to the extent of macrophage activation on histopathology [14, 24, 43]. A higher CSF viral load predicts the future development of HAND [34]. Although the causality scheme virus/viral products $\rightarrow$ histopathologic changes $\rightarrow$ neurocognitive dysfunction is well established with statistical significance, this relationship is not very close. Even in the pre-cART era, the CSF viral load was only slightly higher in HAND 
Table 3 Differential diagnoses of HAND and the relevant diagnostic procedures

\begin{tabular}{|c|c|}
\hline Disease & Useful diagnostic procedures (commentary) \\
\hline $\begin{array}{l}\text { Primary and degenerative dementias } \\
\text { Cerebral small vessel disease, Alzheimer, Lewy-body-dementia, } \\
\text { frontotemporal dementia, normal pressure hydrozephalus, and } \\
\text { Parkinson's disease }\end{array}$ & $\begin{array}{l}\text { History (typical pattern of clinical presentation?) including family } \\
\text { history and arterial hypertension with end organ damage } \\
\text { Thorough neurological examination } \\
\text { Neuropsychological-cognitive profile } \\
\text { Routine MRI, FDG-PET } \\
\text { CSF including "biomarkers" such as A } \beta 42 \text { and tau } \\
\text { CSF opening pressure and, if applicable, drainage of } 20-30 \mathrm{ml} \mathrm{CSF}\end{array}$ \\
\hline Creutzfeld-Jakob disease & 14-3-3-protein and tau in the CSF, EEG, MRI \\
\hline $\begin{array}{l}\text { Cognitive dysfunction with concomitant major depressive disorder } \\
\text { ("pseudodementia") }\end{array}$ & Psychiatric examination \\
\hline Intoxication & Determination of prescription and illicit drugs in plasma and urine \\
\hline Progressive multifocal leukoencephalopathy (PML) & $\begin{array}{l}\text { MRI with white matter lesions (Gadolinium enhancement may occur } \\
\text { with immune reconstitution inflammatory syndrome (IRIS)) } \\
\text { PCR for JC virus in the CSF }\end{array}$ \\
\hline Metabolic encephalopathy and poor general condition & $\begin{array}{l}\text { Blood chemistry (electrolytes, kidney, liver function tests, thyroid } \\
\text { stimul. hormone (TSH) cortisol, differential blood count) } \\
\text { Vitamin- } \text { B }_{12} \text { deficiency (homocysteine and holo-transcobalamine in the } \\
\text { serum) } \\
\text { Hypoxaemia? (blood gas analysis) } \\
\text { Poor general condition? (bed ridden, cachexia, pyrexia) }\end{array}$ \\
\hline Neurosyphilis & Antibody testing including CSF analysis \\
\hline Primary CNS lymphoma & $\begin{array}{l}\text { CT/MRI/PET or SPECT (uni- or multifocal lesions, mostly located } \\
\text { close to the ventricles; reduced diffusion on diffusion-weighted } \\
\text { imaging) }\end{array}$ \\
\hline Toxoplasmosis & $\begin{array}{l}\text { CT/MRI (uni- or multifocal contrast enhancing lesions; enhanced } \\
\text { diffusion in the lesion core on diffusion-weighted imaging) } \\
\text { Antibody testing in blood and CSF (absence of any antibody makes } \\
\text { toxoplasmosis unlikely) }\end{array}$ \\
\hline CMV encephalitis & $\begin{array}{l}\text { CSF including CMV-PCR; pp65 antigen in blood, antibody testing for } \\
\text { CMV; MRI (subependymal contrast enhancement); fundoscopy for } \\
\text { CMV retinitis }\end{array}$ \\
\hline Cryptococcosis & $\begin{array}{l}\text { CSF including opening pressure, ink stain, fungal culture, cryptococcal } \\
\text { antigen in CSF }\end{array}$ \\
\hline VZV encephalitis & CSF including PCR for varicella zoster virus and antibody testing \\
\hline Tuberculous meningitis/other bacterial agents & $\begin{array}{l}\text { CSF including Gram staining, bacterial culture (including Tb), DNA- } \\
\text { based methods } \\
\text { IFN-gamma release assays, Tine test and Mendell-Mantoux test may all } \\
\text { be negative due to immunosuppression }\end{array}$ \\
\hline Hepatitis-C virus infection & Antibody testing, PCR, and liver function tests \\
\hline Immune reconstitution inflammatory syndrome (IRIS) & Well known for Tb, PML, cryptococcosis, and toxoplasmosis \\
\hline
\end{tabular}

subjects vs. non-HAND subjects, and this relation is no more true in the cART era [21, 55, 74, 104].

Infact, in patients on plasma-suppressive cART, despite suffering from HAND, the classical features of HIV encephalitis often are conspicuously absent [37]. Here, metabolic effects, e.g., at the blood-brain interface, and functional changes rather than irreversible structural damage are being discussed as pathogenic factors [42].

Thus, HAND is not caused by a one-dimensional and direct pathogenetic event, but rather by multi-dimensional and complex immunopathological processes that are governed by viral as well as host factors.

With its high genetic variability, HIV rapidly adapts to the cellular and immunologic environment. Early isolated findings on brain-specific genetic HIV sequences could later not be replicated [56]. However, many authors found genetic diversity of CNS virus as compared to virus from systemic compartments such as blood, spleen, and bone marrow, and this difference was more pronounced in HAND vs. non-HAND patients [29, 57, 116]. Multiple 
studies found an at least partial compartmentalisation of virus replication in the CNS and blood, and this was interpreted as evidence for adaptation to organ specific environments [28, 94].

A variety of cytokines and chemokines involved in cellular and humoral immune processes are correlated to the grade of brain infection [85, 114]. The chemokine CCL-2, e.g., that governs the invasion of immunocompetent cells into the CSF and stimulates virus replication, is associated with neurocognitive function [104, 131]. Several authors found specific genotypes (involving, e.g., CCL-2, TNF-alpha, and the Delta-32-deletion of the CCR5 molecule) to predispose to the development of HAND [44, 91, 122].

While in the pre-cART era, the CD4 cell count and the plasma viral load predicted the development of HAND, this is no more true for the cART era. In addition, HAND does now occur in earlier stages of the HIV infection [55]. Several studies have identified the following risk factors for developing HAND: lower education, severe pre-existing immunosuppression, older age, history of AIDSdefining illnesses, high TNF-alpha and MCP-1 plasma concentrations and, most prominently, lower nadir CD4 count $[4,32,96,104,120]$. An international study with, on average, 40-year-old cART-treated participants found an association of cardiovascular diseases and their risk factors (blood pressure and cholesterol) with worse neurocognitive function [132]. For the phenomenon of development and persistence of HAND despite desirable systemic viral and immunologic parameters, several explanations have been proposed. Some studies in patients with long-term suppressed virus load in the plasma and CSF found elevated levels of neopterin and anti-MOG antibodies in the CSF $[27,61]$ and microglial activation on brain positron emission tomography (PET) [40]. This was interpreted as chronic immune activation in the CNS. The dissociation of immunologic events in the CNS from the systemic compartment may suggest persistent low-level virus replication in the brain. In fact, low-level virus production has been found in the CSF of patients by the use of an extra-sensitive PCR protocol detecting down to 2 copies/ml [65].

Nowadays, the most severe manifestations of HAND do almost only affect either untreated or insufficiently treated subjects [37, 90].

Despite the brain infection taking place in the days after primary infection, the development of HAND takes years. As an explanation for this ostensible contradiction, it has been suggested that initially, the brain infection is relatively well controlled, while later, there is a quantitative and qualitative breakdown of immune control in the CNS [89].

Studies showing high copy numbers of HIV DNA in mononuclear cells including monocytes in HAND patients
[59, 107] as well as studies showing high numbers of circulating monocytes in children with HAND [102] suggest a role of macrophages in the pathogenesis. The pathogenic role of the immune response is supported by the phenomenon of the immune reconstitution inflammatory syndrome (IRIS). This may be characterised by marked leukoencephalopathy and an unusual infiltration of CD8positive lymphocytes [46, 124].

Findings of amyloid deposition in the brain parenchyma and pathologically low or high values of $A \beta 42$ and the axonal protein tau, respectively, in the CSF, point to aspects of the Alzheimer's disease pathology [15, 37, 49].

While some authors implicated HCV co-infection in the pathogenesis of HAND, a recent large and well-controlled study found no evidence for worse cognitive function in $\mathrm{HCV}$ co-infected patients, at least in the absence of liver dysfunction [16].

Surprisingly, one study showed improved cognitive function in patients during interruption of long-term and suppressive cART [97]. One possible explanation is mitochondrial toxicity of cART that has been suggested by MR spectroscopy showing reduced levels of the mitochondrial and neuron-associated molecule $N$-acetylaspartate (NAA) in individuals treated with $\mathrm{d} 4 \mathrm{t}$ or ddI [103].

\section{Treatment and prevention}

With the assumption that the HIV infection of the brain is the necessary prerequisite for the development of HAND, the mainstay of a causal treatment is the suppression of virus replication in the brain. In treatment-naïve patients, various studies employing different methodologies have demonstrated this to be an achievable goal. cART leads to a lower virus load in the brain parenchyma as well as in the CSF, there is improvement of electrophysiologic parameters and, finally, a randomised clinical study has demonstrated improved cognitive function [30, 31, 39, 62, 108, 126]. Notable improvement starts some 4-8 months after start of treatment [22]. The degree of clinical improvement is higher in more severely affected patients, and it corresponds to the increase of CD4-lymphocytes [54, 55].

While it is fully accepted that untreated patients with HAND need to be started on cART, the question of how to treat is less clear with patients already on cART. If there still is ongoing plasma virus replication, this should obviously be suppressed by adapting the cART. If plasma virus is suppressed lumbar puncture for the determination of CSF viral load, and if possible, drug-resistant virus should be done. For the detection of CSF virus, an ultrasensitive PCR technique detecting down to 2 copies per ml CSF might be employed, as low-level virus replication was shown to be associated with NCI [65]. In case of ongoing CSF virus 
replication, but also without, further modification into "neuro-active" cART may be reasonable. At this stage, differential diagnoses of HAND also need to be considered (Table 3). The MIND EXCHANGE working group suggested a useful algorithm [77]. The issue of which substances and which combination thereof are best suited for the treatment and prevention of HAND is still under debate. Conventional wisdom suggests an important role of the penetration of antiviral substances into the CSF and brain parenchyma. This is supported by a randomised trial that compared a protease inhibitor (PI) monotherapy (lopinavir, LPV/r) to a dual cART with LPV/r and nucleoside/nucleotide analogues [51]. There was detectable viral load in the CSF with suppressed or very low viral load in the plasma in some of the monotherapy patients.

A CNS penetration effectiveness score (CPE), composed of the relative values of CNS penetration of the substances in a given cART regimen, has been devised by Letendre [63]. It comprises four categories, where lower scores indicate lower CNS penetration (Table 4).

Several authors worked on the impact of the CNS penetration on the CSF viral load and on cognitive clinical endpoints. Most studies showed higher CPE scores to be associated with lower CSF viral loads [20, 23, 64]. Whether this translates into neurocognitive improvement is less clear. A review of observational studies and two more recent observational studies showed only moderate but statistically significant desirable effects [11, 23, 123]. Two small randomized trials prospectively examined cART regimens with higher vs. lower CPE scores. One showed slightly better cognitive results with higher CPE scores [129], and in the other, there was a trend for such an effect in the whole study population and a statistically significant positive effect in the subgroup with suppressed plasma viraemia [33]. One randomised trial tested Maraviroc vs. Tenofovir against the background of Darunavir and Emtricitabine in treatment-naïve patients. There was cognitive improvement in both arms but no difference between the two agents [95].

In a small randomised, controlled pilot trial of cARTintensification with Maraviroc on the background of stable and plasma-suppressive cART, Maraviroc significantly improved cognition [41].

Thus, there is no final proof of better neurocognitive performance with CNS-penetrating antivirals. Nevertheless, at least in patients with symptomatic CNS disease, we recommend to take the CPE score into consideration.

The notion of the importance of suppressing the CNS viral replication is supported by case series that describe patients with long-standing suppression of the plasma viral load but detectable viral replication in the CSF ("viral escape") and cases with resistant viral strains in the CSF $[10,88,112]$. These subjects had clinically overt neurological disease, and on optimization of their cART according to the $\mathrm{CPE}$ score and resistance testing, all improved clinically and in terms of CSF viral load.

The European AIDS Clinical Society in its latest guideline (Oct 2016) recommends to screen for and, if appropriate, to perform the diagnostic steps for HAND. In case of established diagnosis, considering CNS-active drugs is recommended (http://www.eacsociety.org/guide lines/). The US Department of Health and Human Services (HHS), in its latest guideline (July 2016), recommends to consider CNS pharmacokinetics only in the case of clearcut CNS viral escape with clinical manifestations (https:// aidsinfo.nih.gov/guidelines/).

In the differential diagnosis of NCI, toxic effects of cART substances need to be considered. Efavirenz is well
Table 4 CNS penetration effectiveness score (CPE) [63], updated according to Letendre 2014

\begin{tabular}{lllll}
\hline & 4 & 3 & 2 & 1 \\
\hline NRTI's & Zidovudine & Abacavir & $\begin{array}{l}\text { Didanosine } \\
\text { Lamivudine } \\
\text { Emtricitabine }\end{array}$ & Tenofovir \\
& & & Stavudine \\
NNRTI's & Nevirapine & Efavirenz & Rilpivirine & \\
& & Etravirine & & \\
PI's & Indinavir/r & Darunavir/r & Atazanavir & Nelfinavir \\
& & Fosamprenavir/r & Atazanavir/r & Ritonavir \\
& & Indinavir & Fosamprenavir & Saquinavir \\
& & Lopinavir/r & & Saquinavir/r \\
& & & & Tipranavir/r \\
Entry/fusion inhibitors & & Maraviroc & & Enfuvirtide \\
Integrase inhibitors & Dolutegravir & Raltegravir & Elvitegravir & \\
\hline A & & & & \\
\hline
\end{tabular}

A value of $1,2,3$, or 4 is assigned to the different antiviral substances (first line). The CPE values of a patient's cART components are summed up to arrive at the CPE score. A high score stands for better penetration into the CNS 
known to cause neuropsychiatric symptoms, but these tend to wear off with time. Some authors found NCI in patients on stable cART that improved on discontinuation of cART [50, 80, 97], although others failed to replicate these findings. Although structured therapeutic interruptions (STI) arise as a plausible option, these are not recommended as they may cause more harm than benefit. If neurotoxicity is suspected, modification of the cART may be reasonable.

A variety of non-antiretroviral substances such as minocycline, memantine, selegiline, lithium, valproate, lexipafant, nimodipine, psychostimulants, rivastigmine, and others have been tested for the treatment of HAND. None of these exerted a significant clinically beneficial effect $[82,110]$.

Non-pharmacological interventions that may have a positive clinical effect are the treatment of concurrent diseases such as HCV infection with liver dysfunction, major depressive disorder, and cardiovascular and metabolic risk factors, as well as improving the adherence to cART [36].

Some groups advocate screening for HAND, while others are hesitant as there is no scientifically established concept of reacting to pathologic results of screening. Moreover, the comprehensive neurocognitive test battery (the gold standard) is time-consuming and not widely available. There are shorter tests such as the HIV dementia scale [78], the MoCA test [7, 58, 86], and the NEU screen (a combination of the trail-making test $\mathrm{A}$ and $\mathrm{B}$ with a verbal-learning test) [81], but they have limited sensitivity and specificity. If screening is decided, it should be done early after the diagnosis of HIV infection and preferentially prior the commencement of cART as this provides baseline data for longitudinal testing [77]. According to the individual risk constellation, the interval of the screening examinations should be 6-24 months.

The most prominent cognitive feature differentiating HAND from Alzheimer's disease is the memory loss in Alzheimer's which affects encoding as well as retrieval.

For the prevention of HAND, an early start of cART might be beneficial, although there are no randomised studies [19, 32]. The value of CNS-penetrating substances for the prevention of HAND (as opposed to its treatment) is not established.

\section{Outlook}

Considering its treatability, the continuously high number of yearly transmissions and of migrants from endemic regions, the prevalence of HIV infection is bound to increase. The rising age of the HIV-infected population will make it ever more necessary to include non-HIV- associated forms of dementia into the differential diagnoses of HAND. As not all HIV patients will eventually suffer from HAND, specific parameters allowing for risk stratification would be helpful. This includes better instruments for screening and diagnosis. Because, for the time being, HIV cannot be eradicated from the body improved cART substances as well as other principles of preventing and treating HAND are needed.

\section{Practical conclusion}

- The prevalence of HIV infection and the age of the infected population are rising.

- HAND is a subcortical type of cognitive disease with psychomotor slowing as the most salient feature.

- The differentiation from other types of cognitive disorders becomes ever more important.

- The diagnosis of HAND is made on clinical grounds. Ancillary diagnostics steps are done to exclude differential diagnoses.

- HIV patients should be regularly screened for neurocognitive dysfunction.

- For treatment of HAND, CNS-penetrating substances should be considered.

\section{Compliance with ethical standards}

Conflicts of interest On behalf of all authors, the corresponding author states that there is no conflict of interest.

Open Access This article is distributed under the terms of the Creative Commons Attribution 4.0 International License (http://crea tivecommons.org/licenses/by/4.0/), which permits unrestricted use, distribution, and reproduction in any medium, provided you give appropriate credit to the original author(s) and the source, provide a link to the Creative Commons license, and indicate if changes were made.

\section{References}

1. Antinori A, Arendt G, Becker JT, Brew BJ, Byrd DA, Cherner M, Clifford DB, Cinque P, Epstein LG, Goodkin K, Gisslen M, Grant I, Heaton RK, Joseph J, Marder K, Marra CM, McArthur JC, Nunn M, Price RW, Pulliam L, Robertson KR, Sacktor N, Valcour V, Wojna VE (2007) Updated research nosology for HIV-associated neurocognitive disorders. Neurology 69:1789-1799

2. Arendt G, Hefter H, Elsing C, Strohmeyer G, Freund HJ (1990) Motor dysfunction in HIV-infected patients without clinically detectable central-nervous deficit. J Neurol 237:362-368

3. Arendt G, Hefter H, Hilperath F, von Giesen HJ, Strohmeyer G, Freund HJ (1994) Motor analysis predicts progression in HIVassociated brain disease. J Neurol Sci 123:180-185

4. Bhaskaran K, Mussini C, Antinori A, Walker AS, Dorrucci M, Sabin C, Phillips A, Porter K (2008) Changes in the incidence and predictors of human immunodeficiency virus-associated 
dementia in the era of highly active antiretroviral therapy. Ann Neurol 63:213-221

5. Brew B (2004) Evidence for a change in AIDS dementia complex in the era of highly active antiretroviral therapy and the possibility of new forms of AIDS dementia complex. AIDS 18(Suppl 1):S75-S78

6. Brew BJ, Pemberton L, Cunningham P, Law MG (1997) Levels of human immunodeficiency virus type 1 RNA in cerebrospinal fluid correlate with AIDS dementia stage. J Infect Dis 175:963-966

7. Brouillette MJ, Mayo N, Fellows LK, Lebedeva E, Higgins J, Overton ET, Ances BM, Koski L (2015) A better screening tool for HIV-associated neurocognitive disorders: is it what clinicians need? AIDS 29:895-902

8. Budka H (1986) Multinucleated giant cells in brain, a hallmark of the acquired immundeficiency syndrom (AIDS). Acta Neuropathol 69:253-258

9. Budka H, Wiley CA, Kleihues P, Artigas J, Asbury AK, Cho ES, Cornblath DR, Dal Canto MC, DeGirolami U, Dickson D et al (1991) HIV-associated disease of the nervous system: review of nomenclature and proposal for neuropathology-based terminology. Brain Pathol 1:143-152

10. Canestri A, Lescure FX, Jaureguiberry S, Moulignier A, Amiel C, Marcelin AG, Peytavin G, Tubiana R, Pialoux G, Katlama C (2010) Discordance between cerebral spinal fluid and plasma HIV replication in patients with neurological symptoms who are receiving suppressive antiretroviral therapy. Clin Infect Dis 50:773-800

11. Carvalhal A, Gill MJ, Letendre SL, Rachlis A, Bekele T, Raboud J, Burchell A, Rourke SB, Centre for Brain Health in HA (2016) Central nervous system penetration effectiveness of antiretroviral drugs and neuropsychological impairment in the Ontario HIV Treatment Network Cohort Study. J Neurovirol 22:349-357

12. Cherner M, Cysique L, Heaton RK, Marcotte TD, Ellis RJ, Masliah E, Grant I (2007) Neuropathologic confirmation of definitional criteria for human immunodeficiency virus-associated neurocognitive disorders. J Neurovirol 13:23-28

13. Cherner M, Ellis RJ, Lazzaretto D, Young C, Mindt MR, Atkinson JH, Grant I, Heaton RK (2004) Effects of HIV-1 infection and aging on neurobehavioral functioning: preliminary findings. AIDS 18(Suppl 1):S27-S34

14. Cherner M, Masliah E, Ellis RJ, Marcotte TD, Moore DJ, Grant I, Heaton RK (2002) Neurocognitive dysfunction predicts postmortem findings of HIV encephalitis. Neurology 59:1563-1567

15. Clifford DB, Fagan AM, Holtzman DM, Morris JC, Teshome M, Shah AR, Kauwe JS (2009) CSF biomarkers of Alzheimer disease in HIV-associated neurologic disease. Neurology 73:1982

16. Clifford DB, Vaida F, Kao YT, Franklin DR, Letendre SL, Collier AC, Marra CM, Gelman BB, McArthur JC, Morgello S, Simpson DM, Grant I, Heaton RK, Group C (2015) Absence of neurocognitive effect of hepatitis $\mathrm{C}$ infection in HIV-coinfected people. Neurology 84:241-250

17. Cloak CC, Chang L, Ernst T (2004) Increased frontal white matter diffusion is associated with glial metabolites and psychomotor slowing in HIV. J Neuroimmunol 157:147-152

18. Cole MA, Margolick JB, Cox C, Li X, Selnes OA, Martin EM, Becker JT, Aronow HA, Cohen B, Sacktor N, Miller EN (2007) Longitudinally preserved psychomotor performance in longterm asymptomatic HIV-infected individuals. Neurology 69:2213-2220

19. Crum-Cianflone NF, Moore DJ, Letendre S, Poehlman Roediger M, Eberly L, Weintrob A, Ganesan A, Johnson E, Del Rosario R, Agan BK, Hale BR (2013) Low prevalence of neurocognitive impairment in early diagnosed and managed HIV-infected persons. Neurology 80:371-379

20. Cusini A, Vernazza PL, Yerly S, Decosterd LA, Ledergerber B, Fux CA, Rohrbach J, Widmer N, Hirschel B, Gaudenz R, Cavassini M, Klimkait T, Zenger F, Gutmann C, Opravil M, Gunthard HF, Swiss HIVCS (2013) Higher CNS penetrationeffectiveness of long-term combination antiretroviral therapy is associated with better HIV-1 viral suppression in cerebrospinal fluid. J Acquir Immune Defic Syndr Hum Retrovirol 62:28-35

21. Cysique LA, Brew BJ, Halman M, Catalan J, Sacktor N, Price R, Brown S, Atkinson J, Clifford D, Simpson D, Torres G, Hall C, Power C, Marder K, McArthur J, Symonds W, Romero C (2005) Undetectable cerebrospinal fluid HIV RNA and beta-2 microglobulin do not indicate inactive AIDS dementia complex in HAART-treated patients. J Acquir Immune Defic Syndr Hum Retrovirol 39:426-429

22. Cysique LA, Vaida F, Letendre S, Gibson S, Cherner M, Woods SP, McCutchan JA, Heaton RK, Ellis RJ (2009) Dynamics of cognitive change in impaired HIV-positive patients initiating antiretroviral therapy. Neurology 73:342-348

23. Cysique LA, Waters EK, Brew BJ (2011) Central nervous system antiretroviral efficacy in HIV infection: a qualitative and quantitative review and implications for future research. BMC Neurol 11:148

24. Desplats P, Dumaop W, Smith D, Adame A, Everall I, Letendre S, Ellis R, Cherner M, Grant I, Masliah E (2013) Molecular and pathologic insights from latent HIV-1 infection in the human brain. Neurology 80:1415-1423

25. Dore GJ, Correll PK, Li Y, Kaldor JM, Cooper DA, Brew BJ (1999) Changes to AIDS dementia complex in the era of highly active antiretroviral therapy. AIDS 13:1249-1253

26. Eden A, Marcotte TD, Heaton RK, Nilsson S, Zetterberg H, Fuchs D, Franklin D, Price RW, Grant I, Letendre SL, Gisslen M (2016) Increased intrathecal immune activation in virally suppressed HIV-1 infected patients with neurocognitive impairment. PLoS One 11:e0157160

27. Eden A, Price RW, Spudich S, Fuchs D, Hagberg L, Gisslen M (2007) Immune activation of the central nervous system is still present after $>4$ years of effective highly active antiretroviral therapy. J Infect Dis 196:1779-1783

28. Eggers C, Hertogs K, Stuerenburg HJ, van Lunzen J, Stellbrink HJ (2003) Delayed CNS virus suppression during HAART is associated with HIV encephalopathy, but not with viral drug resistance or poor CNS drug penetration. AIDS 17:1897-1906

29. Eggers C, Muller O, Thordsen I, Schreiber M, Methner A (2013) Genetic shift of env V3 loop viral sequences in patients with HIV-associated neurocognitive disorder during antiretroviral therapy. J Neurovirol 19:523-530

30. Eggers C, Stuerenburg HJ, Schafft T, Zöllner B, Stellbrink HJ, van Lunzen J (2000) Rapid clearance of human immunodeficiency virus from ventricular cerebrospinal fluid during antiretroviral treatment. Ann Neurol 47:816-819

31. Eggers C, van Lunzen J, Buhk T, Stellbrink HJ (1999) HIV infection of the central nervous system is characterized by rapid turnover of viral RNA in cerebrospinal fluid. J Acquir Immune Defic Syndr Hum Retrovirol 20:259-264

32. Ellis RJ, Badiee J, Vaida F, Letendre S, Heaton RK, Clifford D, Collier AC, Gelman B, McArthur J, Morgello S, McCutchan JA, Grant I (2011) CD4 nadir is a predictor of HIV neurocognitive impairment in the era of combination antiretroviral therapy. AIDS 25:1747-1751

33. Ellis RJ, Letendre S, Vaida F, Haubrich R, Heaton RK, Sacktor N, Clifford DB, Best BM, May S, Umlauf A, Cherner M, Sanders C, Ballard C, Simpson DM, Jay C, McCutchan JA (2014) Randomized trial of central nervous system-targeted 
antiretrovirals for HIV-associated neurocognitive disorder. Clin Infect Dis 58:1015-1022

34. Ellis RJ, Moore DJ, Childers ME, Letendre S, McCutchan JA, Wolfson T, Spector SA, Hsia K, Heaton RK, Grant I (2002) Progression to neuropsychological impairment in HIV infection predicted by elevated CSF levels of HIV RNA. Arch Neurol 59:923-928

35. Elovaara I, Seppälä I, Poutiainen E, Suni J, Valle SL (1988) Intrathecal humoral immunologic response in neurologically symptomatic and asymptomatic patients with human immunodeficiency virus infection. Neurology 38:1451-1456

36. Ettenhofer ML, Foley J, Castellon SA, Hinkin CH (2010) Reciprocal prediction of medication adherence and neurocognition in HIV/AIDS. Neurology 74:1217-1222

37. Everall I, Vaida F, Khanlou N, Lazzaretto D, Achim C, Letendre S, Moore D, Ellis R, Cherner M, Gelman B, Morgello S, Singer E, Grant I, Masliah E, National Neuro ATC (2009) Cliniconeuropathologic correlates of human immunodeficiency virus in the era of antiretroviral therapy. J Neurovirol 15:360-370

38. Everall IP, Heaton RK, Marcotte TD, Ellis RJ, McCutchan JA, Atkinson JH, Grant I, Mallory M, Masliah E (1999) Cortical synaptic density is reduced in mild to moderate HIV neurocognitive disorder. Brain Pathol 9:209-217

39. Evers S, Grotemeyer KH, Reichelt D, Lüttmann S, Husstedt IW (1998) Impact of antiretroviral treatment on AIDS dementia: a longitudinal prospective event-related potential study. J Acquir Immune Defic Syndr Hum Retrovirol 17:143-148

40. Garvey LJ, Pavese N, Politis M, Ramlackhansingh A, Brooks DJ, Taylor-Robinson SD, Winston A (2013) Increased microglia activation in neurologically asymptomatic HIV-infected patients receiving effective ART; an 11C-PK11195 PET study. AIDS 28:67

41. Gates TM, Cysique LA, Siefried KJ, Chaganti J, Moffat KJ, Brew BJ (2016) Maraviroc-intensified combined antiretroviral therapy improves cognition in virally suppressed HIV-associated neurocognitive disorder. AIDS 30:591-600

42. Gelman BB (2015) Neuropathology of HAND with suppressive antiretroviral therapy: encephalitis and neurodegeneration reconsidered. Curr HIV/AIDS Rep 12:272-279

43. Glass JD, Fedor H, Wesselingh SL, McArthur JC (1995) Immunocytochemical quantitation of human immunodeficiency virus in the brain: correlations with dementia. Ann Neurol 38:755-762

44. Gonzalez E, Rovin BH, Sen L, Cooke G, Dhanda R, Mummidi S, Kulkarni H, Bamshad MJ, Telles V, Anderson SA, Walter EA, Stephan KT, Deucher M, Mangano A, Bologna R, Ahuja SS, Dolan MJ, Ahuja SK (2002) HIV-1 infection and AIDS dementia are influenced by a mutant MCP-1 allele linked to increased monocyte infiltration of tissues and MCP-1 levels. Proc Natl Acad Sci USA 99:13795-13800

45. Grant I, Franklin DR Jr, Deutsch R, Woods SP, Vaida F, Ellis RJ, Letendre SL, Marcotte TD, Atkinson JH, Collier AC, Marra CM, Clifford DB, Gelman BB, McArthur JC, Morgello S, Simpson DM, McCutchan JA, Abramson I, Gamst A, FennemaNotestine C, Smith DM, Heaton RK, Group C (2014) Asymptomatic HIV-associated neurocognitive impairment increases risk for symptomatic decline. Neurology 82:2055-2062

46. Gray F, Chretien F, Vallat-Decouvelaere AV, Scaravilli F (2003) The changing pattern of HIV neuropathology in the HAART era. J Neuropathol Exp Neurol 62:429-440

47. Gray F, Haug H, Chimelli L, Geny C, Gaston A, Scaravilli F, Budka H (1991) Prominent cortical atrophy with neuronal loss as correlate of human immunodeficiency virus encephalopathy. Acta Neuropathol 82:229-233

48. Gray F, Scaravilli F, Everall I, Chretien F, An S, Boche D, AdleBiassette H, Wingertsmann L, Durigon M, Hurtrel B, Chiodi F,
Bell J, Lantos P (1996) Neuropathology of early HIV-1 infection. Brain Pathol 6:1-15

49. Green DA, Masliah E, Vinters HV, Beizai P, Moore DJ, Achim CL (2005) Brain deposition of beta-amyloid is a common pathologic feature in HIV positive patients. AIDS 19:407-411

50. Grund B, Wright EJ, Brew BJ, Price RW, Roediger MP, Bain MP, Hoy JF, Shlay JC, Vjecha MJ, Robertson KR, Group ISS (2013) Improved neurocognitive test performance in both arms of the SMART study: impact of practice effect. J Neurovirol 19:383-392

51. Gutmann C, Cusini A, Günthard HF, Fux C, Hirschel B, Decosterd LA, Cavassini M, Yerly S, Vernazza PL (2010) Randomized controlled study demonstrating failure of LPV/r monotherapy in HIV: the role of compartment and CD4-nadir. AIDS 24:2347

52. Harezlak J, Buchthal S, Taylor M, Schifitto G, Zhong J, Daar E, Alger J, Singer E, Campbell T, Yiannoutsos C, Cohen R, Navia B (2011) Persistence of HIV-associated cognitive impairment, inflammation, and neuronal injury in era of highly active antiretroviral treatment. AIDS 25:625-633

53. Harris MJ, Jeste DV, Gleghorn A, Sewell DD (1991) New-onset psychosis in HIV-infected patients. J Clin Psychiatry 52:369-376

54. Heaton RK, Clifford DB, Franklin DR Jr, Woods SP, Ake C, Vaida F, Ellis RJ, Letendre SL, Marcotte TD, Atkinson JH, Rivera-Mindt M, Vigil OR, Taylor MJ, Collier AC, Marra CM, Gelman BB, McArthur JC, Morgello S, Simpson DM, McCutchan JA, Abramson I, Gamst A, Fennema-Notestine C, Jernigan TL, Wong J, Grant I (2010) HIV-associated neurocognitive disorders persist in the era of potent antiretroviral therapy: CHARTER Study. Neurology 75:2087-2096

55. Heaton RK, Franklin DR, Ellis RJ, McCutchan JA, Letendre SL, Leblanc S, Corkran SH, Duarte NA, Clifford DB, Woods SP, Collier AC, Marra CM, Morgello S, Mindt MR, Taylor MJ, Marcotte TD, Atkinson JH, Wolfson T, Gelman BB, McArthur JC, Simpson DM, Abramson I, Gamst A, Fennema-Notestine C, Jernigan TL, Wong J, Grant I (2011) HIV-associated neurocognitive disorders before and during the era of combination antiretroviral therapy: differences in rates, nature, and predictors. J Neurovirol 17:3-16

56. Holman AG, Mefford ME, O'Connor N, Gabuzda D (2010) HIVBrainSeqDB: a database of annotated HIV envelope sequences from brain and other anatomical sites. AIDS Res Ther $7: 43$

57. Hughes ES, Bell JE, Simmonds P (1997) Investigation of the dynamics of the spread of human immunodeficiency virus to brain and other tissues by evolutionary analysis of sequences from the p17gag and env genes. J Virol 71:1272-1280

58. Janssen MA, Bosch M, Koopmans PP, Kessels RP (2015) Validity of the Montreal Cognitive Assessment and the HIV Dementia Scale in the assessment of cognitive impairment in HIV-1 infected patients. J Neurovirol 21:383-390

59. Kallianpur KJ, Shikuma C, Kirk GR, Shiramizu B, Valcour V, Chow D, Souza S, Nakamoto B, Sailasuta N (2013) Peripheral blood HIV DNA is associated with atrophy of cerebellar and subcortical gray matter. Neurology 80:1792-1799

60. Küper M, Rabe K, Esser S, Gizewski ER, Husstedt IW, Maschke M, Obermann M (2011) Structural gray and white matter changes in patients with HIV. J Neurol 258:1066-1075

61. Lackner P, Kuenz B, Reindl M, Morandell M, Berger T, Schmutzhard E, Eggers C (2010) Antibodies to myelin oligodendrocyte glycoprotein in HIV-1 associated neurocognitive disorder: a cross-sectional cohort study. J Neuroinflammation 7:79

62. Langford D, Marquie-Beck J, de Almeida S, Lazzaretto D, Letendre S, Grant I, McCutchan JA, Masliah E, Ellis RJ (2006) 
Relationship of antiretroviral treatment to postmortem brain tissue viral load in HIV-infected patients. J Neurovirol 12:100-107

63. Letendre S (2011) Central nervous system complications in HIV disease: HIV-associated neurocognitive disorder. Top Antivir Med 19:137-142

64. Letendre S, Marquie-Beck J, Capparelli E, Best B, Clifford D, Collier AC, Gelman BB, McArthur JC, McCutchan JA, Morgello S, Simpson D, Grant I, Ellis RJ (2008) Validation of the CNS Penetration-effectiveness rank for quantifying antiretroviral penetration into the CNS. Arch Neurol 65:65-70

65. Letendre S, McClernon D, Ellis R (2009) Persistent HIV in the central nervous system during treatment is associated with worse ART penetration and cognitive impairment. In: 16th Conference on retroviruses and opportunistic infections (CROI), Montreal

66. Levine AJ, Soontornniyomkij V, Achim CL, Masliah E, Gelman BB, Sinsheimer JS, Singer EJ, Moore DJ (2016) Multilevel analysis of neuropathogenesis of neurocognitive impairment in HIV. J Neurovirol 22:431-441

67. Lezak MD, Howieson DB, Loring DW (2004) Neuropsychological assessment. Oxford University Press, New York

68. Lohse N, Obel N (2016) Update of survival for persons with HIV infection in Denmark. Ann Intern Med 165:749-750

69. Marcotte TD, Deutsch R, McCutchan JA, Moore DJ, Letendre S, Ellis RJ, Wallace MR, Heaton RK, Grant I (2003) Prediction of incident neurocognitive impairment by plasma HIV RNA and CD4 levels early after HIV seroconversion. Arch Neurol 60:1406-1412

70. Marra CM, Maxwell CL, Collier AC, Robertson KR, Imrie A (2007) Interpreting cerebrospinal fluid pleocytosis in HIV in the era of potent antiretroviral therapy. BMC Infect Dis 7:37

71. Mateen FJ, Mills EJ (2012) Aging and HIV-related cognitive loss. JAMA 308:349-350

72. Mc Arthur JC, Hoover DR, Bacellar H, Miller EN, Cohen BA, Becker JT, Graham MNH, McArthur JH, Selnes OA, Jacobson LP, Vissher BR, Concha M, Saah A (1993) Dementia in AIDSpatients: incidence and risk factors. Neurology 43:2245-2252

73. Mc Arthur JC, Mc Clernon DR, Cronin MF, Nance-Sproson TE, Saah JA, St Clair M, Lanier ER (1997) Relationship between HIV-associated dementia and viral load in cerebrospinal fluid and brain. Ann Neurol 42:689-698

74. Mc Arthur JC, Mc Dermott MP, Mc Clernon D et al (2004) Attenuated CNS infection in advanced HIV/AIDS with combination antiretroviral therapy. Arch Neurol 61:1687-1696

75. Mc Cutchan JA, Wu JW, Robertson K, Koletar SL, Ellis RJ, Cohn S, Taylor M, Woods S, Heaton R, Currier J, Williams PL (2007) HIV suppression by HAART preserves cognitive function in advanced, immune-reconstituted AIDS patients. AIDS 21:1109-1117

76. McMurtray A, Nakamoto B, Shikuma C, Valcour V (2007) Small-vessel vascular disease in HIV infection: the Hawaii aging with HIV cohort study. Cerebrovasc Dis 24:236-241

77. Mind Exchange Working Group, Arendt G, Grant I, Letendre SC, Munoz-Moreno JA, Eggers C, Brew B, Brouillette MJ, Bernal-Cano F, Carvalhal A, Christo PP, Cinque P, Cysique L, Ellis R, Everall I, Gasnault J, Husstedt I, Korten V, Machala L, Obermann M, Ouakinin S, Podzamczer D, Portegies P, Rackstraw S, Rourke S, Sherr L, Streinu-Cercel A, Winston A, Wojna V, Yazdanpannah Y, Arbess G, Baril JG, Begovac J, Bergin C, Bonfanti P, Bonora S, Brinkman K, Canestri A, Cholewinska-Szymanska G, Chowers M, Cooney J, Corti M, Doherty C, Elbirt D, Esser S, Florence E, Force G, Gill J, Goffard JC, Harrer T, Li P, de Kerckhove LV, Knecht G, Matsushita S, Matulionyte R, McConkey S, Mouglignier A, Oka S, Penalva A, Riesenberg K, Sambatakou H, Tozzi V, Vassallo M, Wetterberg P, Drapato AW (2013) Assessment, diagnosis, and treatment of HIV-associated neurocognitive disorder: a consensus report of the mind exchange program. Clin Infect Dis 56:1004-1017

78. Morgan EE, Woods SP, Scott JC, Childers M, Beck JM, Ellis RJ, Grant I, Heaton RK, Group TH (2008) Predictive validity of demographically adjusted normative standards for the HIV Dementia Scale. J Clin Exp Neuropsychol 30:83-90

79. Morris L, Silber E, Sonnenberg P, Eintracht S, Nyoka S, Lyons SF, Saffer S, Koornhof H, Martin DJ (1998) High HIV-1 RNA load in the cerebrospinal fluid from patients with lymphocytic meningitis. J Infect Dis 177:473-476

80. Munoz-Moreno JA, Fumaz CR, Prats A, Ferrer MJ, Negredo E, Perez-Alvarez N, Molto J, Gomez G, Garolera M, Clotet B (2010) Interruptions of antiretroviral therapy in HIV-infection: are they detrimental to neurocognitive functioning? J Neurovirol 16:208-218

81. Munoz-Moreno JA, Prats A, Perez-Alvarez N, Fumaz CR, Garolera M, Doval E, Negredo E, Ferrer MJ, Clotet B, Group NEUS (2013) A brief and feasible paper-based method to screen for neurocognitive impairment in HIV-infected patients: the NEU screen. J Acquir Immune Defic Syndr Hum Retrovirol 63:585-592

82. Nakasujja N, Miyahara S, Evans S, Lee A, Musisi S, Katabira E, Robertson K, Ronald A, Clifford DB, Sacktor N (2013) Randomized trial of minocycline in the treatment of HIV-associated cognitive impairment. Neurology 80:196-202

83. Navia BA, Jordan BD, Price RW (1986) The AIDS dementia complex: I. Clinical features. Ann Neurol 19:517-524

84. Neuen-Jacob E (2009) Neurotransmitter effects in human immunodeficiency virus (HIV) and simian immuno-deficiency virus (SIV) infection. AntiInflammatory Antiallergy Agents Med Chem 8:153-163

85. Nolting T, Lindecke A, Koutsilieri E, Maschke M, Husstedt IW, Sopper S, Stuve O, Hartung HP, Arendt G (2009) Measurement of soluble inflammatory mediators in CSF of HIV-positive patients at distinct stages of infection by solid-phase protein array. J Neurovirol 15:390-400

86. Overton ET, Azad TD, Parker N, Demarco Shaw D, Frain J, Spitz T, Westerhaus E, Paul R, Clifford DB, Ances BM (2013) The Alzheimer's disease- 8 and Montreal Cognitive Assessment as screening tools for neurocognitive impairment in HIV-infected persons. J Neurovirol 19:109-116

87. Pang S, Koyanagi Y, Miles S, Wiley C, Vinters HV, Chen IS (1990) High levels of unintegrated HIV-1 DNA in brain tissue of AIDS dementia patients. Nature 343:85-89

88. Peluso MJ, Ferretti F, Peterson J, Lee E, Fuchs D, Boschini A, Gisslen M, Angoff N, Price RW, Cinque P, Spudich S (2012) Cerebrospinal fluid HIV escape associated with progressive neurologic dysfunction in patients on antiretroviral therapy with well controlled plasma viral load. AIDS 26:1765-1774

89. Persidsky Y, Poluektova L (2006) Immune privilege and HIV-1 persistence in the CNS. Immunol Rev 213:180-194

90. Price RW, Spudich S (2008) Antiretroviral therapy and central nervous system HIV type 1 infection. J Infect Dis 197(Suppl 3):S294-S306

91. Quasney MW, Zhang Q, Sargent S, Mynatt M, Glass J, McArthur J (2001) Increased frequency of the tumor necrosis factoralpha-308 A allele in adults with human immunodeficiency virus dementia. Ann Neurol 50:157-162

92. Ragin AB, Du H, Ochs R, Wu Y, Sammet CL, Shoukry A, Epstein LG (2012) Structural brain alterations can be detected early in HIV infection. Neurology 79:2328-2334

93. Ragin AB, Wu Y, Storey P, Cohen BA, Edelman RR, Epstein LG (2005) Diffusion tensor imaging of subcortical brain injury in patients infected with human immunodeficiency virus. J Neurovirol 11:292-298 
94. Ritola K, Robertson K, Fiscus SA, Hall C, Swanstrom R (2005) Increased HIV-1 env compartmentalization in the presence of HIV-1-associated dementia. J Virol 79:10830-10834

95. Robertson KR, Miyahara S, Lee A, Brown TT, Chan ES, Berzins B, Rusin D, Eron JJ, Taiwo BO, Team ACTG (2016) Neurocognition with maraviroc compared with tenofovir in HIV. AIDS 30:2315-2321

96. Robertson KR, Smurzynski M, Parsons TD, Wu K, Bosch RJ, Wu J, McArthur JC, Collier AC, Evans SR, Ellis RJ (2007) The prevalence and incidence of neurocognitive impairment in the HAART era. AIDS 21:1915-1921

97. Robertson KR, Su Z, Margolis DM, Krambrink A, Havlir DV, Evans S, Skiest DJ (2010) Neurocognitive effects of treatment interruption in stable HIV-positive patients in an observational cohort. Neurology 74:1260

98. Robinson-Papp J, Byrd D, Mindt MR, Oden NL, Simpson DM, Morgello S (2008) Motor function and human immunodeficiency virus-associated cognitive impairment in a highly active antiretroviral therapy-era cohort. Arch Neurol 65:1096-1101

99. Sacktor N, Lyles RH, Skolasky R, Kleeberger C, Selnes OA, Miller EN, Becker JT, Cohen B, McArthur JC (2001) HIVassociated neurologic disease incidence changes: multicenter AIDS Cohort Study, 1990-1998. Neurology 56:257-260

100. Sacktor N, Skolasky RL, Seaberg E, Munro C, Becker JT, Martin E, Ragin A, Levine A, Miller E (2016) Prevalence of HIV-associated neurocognitive disorders in the Multicenter AIDS Cohort Study. Neurology 86:334-340

101. Sacktor NC, Wong M, Nakasujja N, Skolasky RL, Selnes OA, Musisi S, Robertson K, McArthur JC, Ronald A, Katabira E (2005) The International HIV Dementia Scale: a new rapid screening test for HIV dementia. AIDS 19:1367-1374

102. Sanchez-Ramon S, Bellon JM, Resino S, Canto-Nogues C, Gurbindo D, Ramos JT, Munoz-Fernandez MA (2003) Low blood $\mathrm{CD}^{+} \mathrm{T}$-lymphocytes and high circulating monocytes are predictors of HIV-1-associated progressive encephalopathy in children. Pediatrics 111:E168-E175

103. Schweinsburg BC, Taylor MJ, Alhassoon OM, Gonzalez R, Brown GG, Ellis RJ, Letendre S, Videen JS, McCutchan JA, Patterson TL, Grant I (2005) Brain mitochondrial injury in human immunodeficiency virus-seropositive $\left(\mathrm{HIV}^{+}\right)$individuals taking nucleoside reverse transcriptase inhibitors. J Neurovirol 11:356-364

104. Sevigny JJ, Albert SM, McDermott MP, McArthur JC, Sacktor N, Conant K, Schifitto G, Selnes OA, Stern Y, McClernon DR, Palumbo D, Kieburtz K, Riggs G, Cohen B, Epstein LG, Marder K (2004) Evaluation of HIV RNA and markers of immune activation as predictors of HIV-associated dementia. Neurology 63:2084-2090

105. Sevigny JJ, Albert SM, McDermott MP, Schifitto G, McArthur JC, Sacktor N, Conant K, Selnes OA, Stern Y, McClernon DR, Palumbo D, Kieburtz K, Riggs G, Cohen B, Marder K, Epstein LG (2007) An evaluation of neurocognitive status and markers of immune activation as predictors of time to death in advanced HIV infection. Arch Neurol 64:97-102

106. Shaw GM, Harper ME, Hahn BH, Epstein LG, Gajdusek DC, Price RW, Navia BA, Petito CK, O`Hara CJ, Groopman JE, Cho ES, Oleske JM, Wong-Staal F, Gallo RC (1985) HTLV-III infection in brains of children and adults with AIDS encephalopathy. Science 227:177-182

107. Shiramizu B, Gartner S, Williams A, Shikuma C, Ratto-Kim S, Watters M, Aguon J, Valcour V (2005) Circulating proviral HIV DNA and HIV-associated dementia. AIDS 19:45-52

108. Sidtis JJ, Gatsonis C, Price RW, Singer EJ, Collier AC, Richman DD, Hirsch MS, Schaerf FW, Fischl MA, Kieburtz K, Simpson D, Koch MA, Feinberg J, Dafni U (1993) Zidovudine treatment of the AIDS dementia complex: results of a placebo-controlled trial. Ann Neurol 33:343-349

109. Silva K, Hope-Lucas C, White T, Hairston TK, Rameau T, Brown A (2015) Cortical neurons are a prominent source of the proinflammatory cytokine osteopontin in HIV-associated neurocognitive disorders. J Neurovirol 21:174-185

110. Simioni S, Cavassini M, Annoni JM, Metral M, Iglesias K, Rimbault Abraham A, Jilek S, Calmy A, Muller H, Fayet-Mello A, Giacobini E, Hirschel B, Du Pasquier RA (2013) Rivastigmine for HIV-associated neurocognitive disorders: a randomized crossover pilot study. Neurology 80:553-560

111. Simioni S, Cavassini M, Annoni JM, Rimbault Abraham A, Bourquin I, Schiffer V, Calmy A, Chave JP, Giacobini E, Hirschel B, Du Pasquier RA (2010) Cognitive dysfunction in HIV patients despite long-standing suppression of viremia. AIDS 24:1243-1250

112. Smit TK, Brew BJ, Tourtellotte W, Morgello S, Gelman BB, Saksena NK (2004) Independent evolution of HIV drug resistance mutations in diverse areas of the brain in HIV-infected patients, with and without dementia, on antiretroviral treatment. J Virol 78:10133-10148

113. Snider WD, Simpson DM, Nielsen S, Gold JW, Metroka CE, Posner JB (1983) Neurological complications of acquired immune deficiency syndrome: analysis of 50 patients. Ann Neurol 14:403-418

114. Sporer B, Kastenbauer S, Koedel U, Arendt G, Pfister HW (2003) Increased intrathecal release of soluble fractalkine in HIV-infected patients. AIDS Res Hum Retroviruses 19:111-116

115. Steinbrink F, Evers S, Buerke B, Young P, Arendt G, Koutsilieri E, Reichelt D, Lohmann H, Husstedt IW (2013) Cognitive impairment in HIV infection is associated with MRI and CSF pattern of neurodegeneration. Eur J Neurol 20:420-428

116. Stingele K, Haas J, Zimmermann T, Stingele R, Hubsch-Muller C, Freitag M, Storch-Hagenlocher B, Hartmann M, Wildemann B (2001) Independent HIV replication in paired CSF and blood viral isolates during antiretroviral therapy. Neurology $56: 355-361$

117. Su T, Wit FW, Caan MW, Schouten J, Prins M, Geurtsen GJ, Cole JH, Sharp DJ, Richard E, Reneman L, Portegies P, Reiss P, Majoie CB, Study AGC (2016) White matter hyperintensities in relation to cognition in HIV-infected men with sustained suppressed viral load on combination antiretroviral therapy. AIDS 30:2329-2339

118. Teo I, Veryard C, Barnes H, An SF, Jones M, Lantos PL, Luthert P, Shaunak S (1997) Circular forms of unintegrated HIV-1 DNA and high levels of viral protein expression: association with dementia and multinucleated giant cells in the brains of patients with AIDS. J Virol 71:2928-2933

119. Thames AD, Becker BW, Marcotte TD, Hines LJ, Foley JM, Ramezani A, Singer EJ, Castellon SA, Heaton RK, Hinkin CH (2011) Depression, cognition, and self-appraisal of functional abilities in HIV: an examination of subjective appraisal versus objective performance. Clin Neuropsychol 25:224-243

120. Tozzi V, Balestra P, Bellagamba R, Corpolongo A, Salvatori MF, Visco-Comandini U, Vlassi C, Giulianelli M, Galgani S, Antinori A, Narciso P (2007) Persistence of neuropsychologic deficits despite long-term highly active antiretroviral therapy in patients with HIV-related neurocognitive impairment: prevalence and risk factors. J Acquir Immune Defic Syndr Hum Retrovirol 45:174-182

121. Valcour V, Shikuma C, Shiramizu B, Watters M, Poff P, Selnes O, Holck P, Grove J, Sacktor N (2004) Higher frequency of dementia in older HIV-1 individuals: the Hawaii Aging with HIV-1 Cohort. Neurology 63:822-827

122. van Rij RP, Portegies P, Hallaby T, Lange JM, Visser J, Husman AM, van 't Wout AB, Schuitemaker H (1999) Reduced 
prevalence of the CCR5 Delta32 heterozygous genotype in HIVinfected individuals with AIDS dementia complex. J Infect Dis 180:854-857

123. Vassallo M, Durant J, Biscay V, Lebrun-Frenay C, Dunais B, Laffon M, Harvey-Langton A, Cottalorda J, Ticchioni M, Carsenti H, Pradier C, Dellamonica P (2014) Can high central nervous system penetrating antiretroviral regimens protect against the onset of HIV-associated neurocognitive disorders? AIDS 28:493-501

124. Venkataramana A, Pardo CA, McArthur JC, Kerr DA, Irani DN, Griffin JW, Burger P, Reich DS, Calabresi PA, Nath A (2006) Immune reconstitution inflammatory syndrome in the CNS of HIV-infected patients. Neurology 67:383-388

125. von Einsiedel RW, Berger $\mathrm{T}$, Weisbrod $\mathrm{M}$, Unverricht $\mathrm{S}$, Hartmann M (2001) HIV patients with psychiatric illnesses. Treatment strategies and drug interactions. Nervenarzt $72: 204-215$

126. von Giesen HJ, Koller H, Theisen A, Arendt G (2002) Therapeutic effects of nonnucleoside reverse transcriptase inhibitors on the central nervous system in HIV-1-infected patients. J Acquir Immune Defic Syndr Hum Retrovirol 29:363-367

127. Wallace MR, Nelson JA, McCutchan JA, Wolfson T, Grant I (2001) Symptomatic HIV seroconverting illness is associated with more rapid neurological impairment. Sex Transm Infect 77:199-201
128. Wiley CA, Achim CL, Christopherson C, Kidane Y, Kwok S, Masliah E, Mellors J, Radhakrishnan L, Wang G, Soontornniyomkij V (1999) HIV mediates a productive infection of the brain. AIDS 13:2055-2059

129. Winston A, Duncombe C, Li PC, Gill JM, Kerr SJ, Puls R, Petoumenos K, Taylor-Robinson SD, Emery S, Cooper DA (2010) Does choice of combination antiretroviral therapy (cART) alter changes in cerebral function testing after 48 weeks in treatment-naive, HIV-1-infected individuals commencing cART? A randomized, controlled study. Clin Infect Dis 50:920-929

130. Wong MC, Suite NDA, Labar DR (1990) Seizures in human immunodeficiency virus infection. Arch Neurol 47:640-642

131. Woods SP, Morgan EE, Marquie-Beck J, Carey CL, Grant I, Letendre SL (2006) Markers of macrophage activation and axonal injury are associated with prospective memory in HIV-1 disease. Cogn Behav Neurol 19:217-221

132. Wright EJ, Grund B, Robertson K, Brew BJ, Roediger M, Bain MP, Drummond F, Vjecha MJ, Hoy J, Miller C, Penalva de Oliveira AC, Pumpradit W, Shlay JC, El-Sadr W, Price RW (2010) Cardiovascular risk factors associated with lower baseline cognitive performance in HIV-positive persons. Neurology $75: 864-873$ 